\title{
Annual layering in the NGRIP ice core during the Eemian
}

\author{
A. Svensson ${ }^{1}$, M. Bigler ${ }^{2}$, E. Kettner ${ }^{1}$, D. Dahl-Jensen ${ }^{1}$, S. Johnsen ${ }^{1}$, S. Kipfstuhl ${ }^{3}$, M. Nielsen ${ }^{1}$, and J. P. Steffensen ${ }^{1}$ \\ ${ }^{1}$ Centre for Ice and Climate, Niels Bohr Institute, University of Copenhagen, Juliane Maries Vej 30, \\ 2100 Copenhagen $\varnothing$, Denmark \\ ${ }^{2}$ Climate and Environmental Physics, Physics Institute, and Oeschger Centre for Climate Change Research, \\ University of Bern, Sidlerstrasse 5, 3012 Bern, Switzerland \\ ${ }^{3}$ Alfred Wegener Institute, Glaciology, Columbusstrasse, 27568 Bremerhaven, Germany
}

Received: 5 February 2011 - Published in Clim. Past Discuss.: 28 February 2011

Revised: 11 November 2011 - Accepted: 14 November 2011 - Published: 16 December 2011

\begin{abstract}
The Greenland NGRIP ice core continuously covers the period from present day back to $123 \mathrm{ka}$ before present, which includes several thousand years of ice from the previous interglacial period, MIS 5e or the Eemian. In the glacial part of the core, annual layers can be identified from impurity records and visual stratigraphy, and stratigraphic layer counting has been performed back to $60 \mathrm{ka}$. In the deepest part of the core, however, the ice is close to the pressure melting point, the visual stratigraphy is dominated by crystal boundaries, and annual layering is not visible to the naked eye. In this study, we apply a newly developed setup for high-resolution ice core impurity analysis to produce continuous records of dust, sodium and ammonium concentrations as well as conductivity of melt water. We analyzed three $2.2 \mathrm{~m}$ sections of ice from the Eemian and the glacial inception. In all of the analyzed ice, annual layers can clearly be recognized, most prominently in the dust and conductivity profiles. Part of the samples is, however, contaminated in dust, most likely from drill liquid. It is interesting that the annual layering is preserved despite a very active crystal growth and grain boundary migration in the deep and warm NGRIP ice. Based on annual layer counting of the new records, we determine a mean annual layer thickness close to $11 \mathrm{~mm}$ for all three sections, which, to first order, confirms the modeled NGRIP time scale (ss09sea). The counting does, however, suggest a longer duration of the climatically warmest part of the NGRIP record (MIS5e) of up to $1 \mathrm{ka}$ as compared to the model estimate. Our results sug-
\end{abstract}

Correspondence to: A. Svensson (as@gfy.ku.dk) gest that stratigraphic layer counting is possible basically throughout the entire NGRIP ice core, provided sufficiently highly-resolved profiles become available.

\section{Introduction}

The previous interglacial period, Marine Isotope Substage 5e (MIS5e) or the Eemian period in the European Pleistocene stratigraphy, approximately covers the time interval 130-115 kyr BP (Shackleton et al., 2003; Cheng et al., 2009; Brauer et al., 2007), although the first sign of Termination II may have appeared as early as $141 \mathrm{ka}$ BP (Drysdale et al., 2009). The Eemian is known to have had warmer climate than present day climate (Turney and Jones, 2010), and the Eemian sea level may have been as much as 6-8 m above present day sea level (Kopp et al., 2009). The Eemian climate may in some regards resemble a future climate, if global warming continues as predicted by IPCC, and a full understanding of the climate conditions during this "natural" warm interglacial period is, therefore, of great interest. Overall, the climate in MIS5e is thought to have been rather stable although some smaller fluctuations may have appeared (Couchoud et al., 2009).

The $3085 \mathrm{~m}$ long NGRIP ice core from Central Greenland continuously covers the past $123 \mathrm{kyr}$, and it thus contains several thousand years of ice deposited during the Eemian period (Dahl-Jensen et al., 2002; North Greenland Ice Core Project members, 2004). The NGRIP climate record is continuous all the way to bedrock (Landais et al., 2006), i.e. there are no large scale disturbances of the type observed in the deepest parts of the GRIP and GISP2 cores (Suwa et al.,

Published by Copernicus Publications on behalf of the European Geosciences Union. 


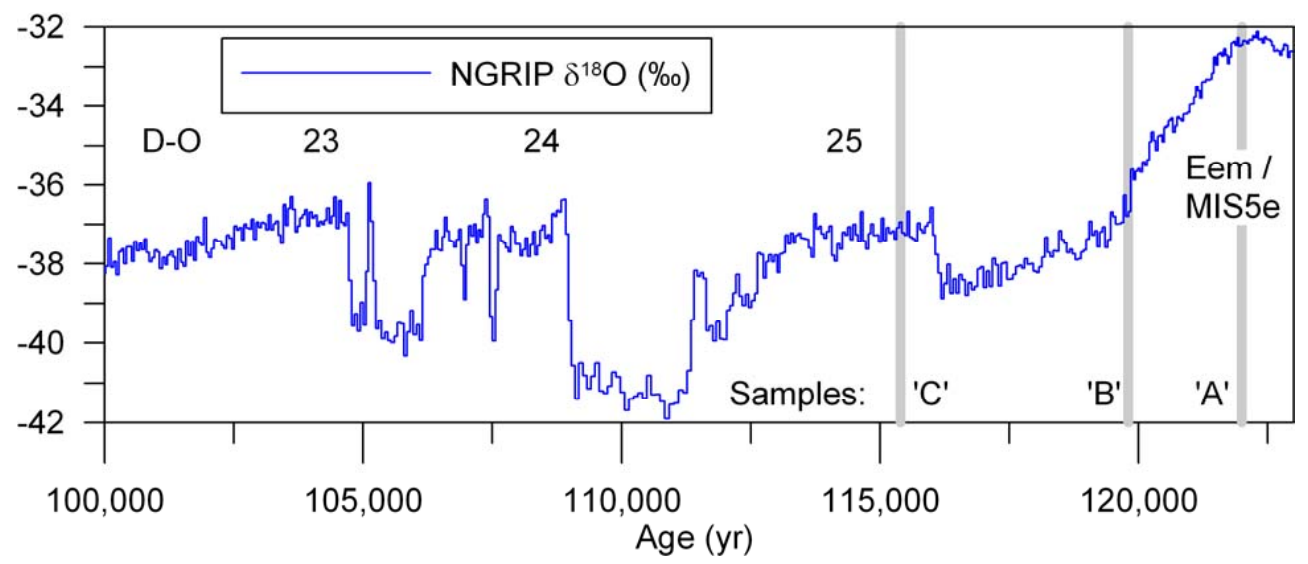

Fig. 1. The NGRIP $\delta^{18} \mathrm{O}$ profile with indication of Dansgaard-Oeschger events (D-O) and the sampled ice core sections. The three $2.2 \mathrm{~m}$ sample sections are taken at the depths indicated by the gray vertical lines. The samples are referred to as "A", "B", and "C" as indicated. See Table 1 for further sample details.

2006). In the deepest part of the NGRIP core, the visual stratigraphy record is, however, dominated by ice crystal boundaries (Svensson et al., 2005) and annual banding is generally not visible to the naked eye. There is basal melting at the NGRIP site and the deepest part of the core is close to the pressure melting point (Dahl-Jensen et al., 2003). The annual layering may, therefore, be disturbed for example by micro folds or by rapid crystal growth in the warm environment (Faria et al., 2010).

High resolution records of impurities and visual stratigraphy have allowed for construction of a $60 \mathrm{ka}$ chronology for the NGRIP ice core by annual layer counting (Svensson et al., 2008; Andersen et al., 2006). Pronounced annual banding in the visual stratigraphy profile beyond $60 \mathrm{ka}$ suggests that the time scale can be further extended (Svensson et al., 2005), but at this depth annual layers are thin and difficult to identify based on available records. The NGRIP modeled time scale predicts annual layers are on the order of $1 \mathrm{~cm}$ thickness at around $115 \mathrm{ka}$, and the core may therefore provide an outstanding opportunity to establish an absolute time scale for the entire last glacial cycle if the annual layering is preserved in the oldest ice.

Recently, a new high-resolution continuous flow analysis (CFA) system for analysis of water soluble constituents and insoluble dust in ice cores has been developed at the University of Copenhagen (Bigler et al., 2011). The system determines the content of soluble sodium (mainly deriving from sea salt), soluble ammonium (related to biological processes and biomass burning events), insoluble dust particles (mostly transported from Asian deserts to Greenland), and the electrolytic melt water conductivity (which is a bulk signal for all ionic constituents). Measurements of early Holocene NGRIP ice on the new system show results compatible with existing NGRIP and GRIP CFA profiles (Bigler et al., 2011). The depth resolution of the new setup is, however, superior compared to existing systems and allows resolving annual lay- ers of down to $1 \mathrm{~cm}$ thickness. With the new high-resolution CFA system, it may therefore be possible to identify annual layers throughout the NGRIP ice core if they are still present.

In this study, we apply the newly developed highresolution CFA system to measure the impurity content of three $2.2 \mathrm{~m}$ NGRIP ice core sections from the Eemian and the glacial interception. We investigate if annual layers are detectable in this deep ice and we make comparisons to wellknown impurity levels of the Holocene. Furthermore, we discuss ice core impurity diffusion and implications for the NGRIP time scale.

\section{Samples and methods}

In the glacial part of the NGRIP ice core, a number of records have been obtained, including the water isotope $\delta^{18} \mathrm{O}$, electrical conductivity measurement (ECM) on the ice surface, continuous flow analysis (CFA) of several chemical components, electrolytic conductivity and dust, as well as a visual stratigraphy (VS) profile. However, in the deepest $85 \mathrm{~m}$ of the core (3000-3085 m depth) that contains the Eemian ice, only measurements of $\delta^{18} \mathrm{O}, \mathrm{ECM}$, and visual stratigraphy have been performed continuously.

The samples for the present study were selected based on the $\delta^{18} \mathrm{O}$ climate proxy curve and from visual inspection of the core to obtain long unbroken pieces. The deepest ice was close to the pressure melting point in the bore hole, which made drilling difficult and the ice brittle when brought to surface. Therefore, many core breaks have occurred during drilling and subsequent core handling. The selected samples are some of the most well-preserved sections and they are of better quality than the average deep NGRIP ice. Three $2.2 \mathrm{~m}$ sections of NGRIP ice were selected around 2996, 3040, and $3070 \mathrm{~m}$ depth: respectively, one section from Greenland Interstadial 25 (GI-25), one section from the termination of the 
Eemian, and one section from the warmest part of the Eemian in NGRIP from just $15 \mathrm{~m}$ above bedrock (Table 1 and Fig. 1). The samples have been stored in the Copenhagen ice core storage facility at a temperature of $-25^{\circ} \mathrm{C}$ and were cut to dimensions of $34 \times 34 \times 550 \mathrm{~mm}^{3}$. End surfaces and breaks in the samples were removed before analysis.

An example of the samples visual stratigraphy is shown in Fig. 2. The NGRIP visual stratigraphy is obtained continuously by a dark field photography method, such that dark areas represent transparent (clean) ice whereas white areas indicate obstacles in the ice such as air bubbles or impurities (Svensson et al., 2005). The visual stratigraphy of the sampled ice is dominated by ice crystal boundaries. The crystals are large, in the $1-10 \mathrm{~cm}$ range, in particular in the deepest sample. Occasionally, a faint horizontal layering is visible within the crystals, but except for the crystal boundaries, the ice is very clean (transparent) as it is common for interglacial ice with low impurity content.

The samples were analyzed using a new setup for highresolution CFA analysis of ice cores (Bigler et al., 2011). The setup measures the mass concentration of water soluble ammonium $\left(\mathrm{NH}_{4}^{+}\right)$, sodium $\left(\mathrm{Na}^{+}\right)$, the electrolytic conductivity of melt water (hereafter "conductivity"), and the amount of insoluble dust particles (hereafter "dust"). The setup has demonstrated a depth resolution that enables us to resolve features of down to $1 \mathrm{~cm}$ thickness.

\section{Results}

Results from the deepest sample "A" are shown in Fig. 3 and the complete measurement series are shown in Figs. S1-S3 in the Supplement. Whereas ammonium, sodium and conductivity show rather constant concentration levels, the dust concentrations occasionally show unusually elevated levels 5-20 times above the background level. Those strongly elevated dust peaks are most likely caused by contamination with drill liquid that may have entered the ice core through cracks in the ice, maybe produced during the drilling process. The dust contamination peaks are often but not consistently associated with the visible grain boundaries, which may have facilitated the formation of cracks. The contaminated dust sections can be discriminated not only from the elevated concentration levels but also from the dust size distribution (not shown) that shows a different pattern from that of the regular ice core dust. All contaminated dust sections have been removed for further discussions (Fig. 3). Fortunately, the other measured parameters show no sign of contamination in the sections of elevated dust.

\section{Profile smoothing over 110 ka}

Figure 4 compares power density spectra of $2.0 \mathrm{~m}$ impurity records of early Holocene NGRIP ice (data from Bigler et al., 2011) with $2.0 \mathrm{~m}$ of ice from the Eemian sample "A" and the

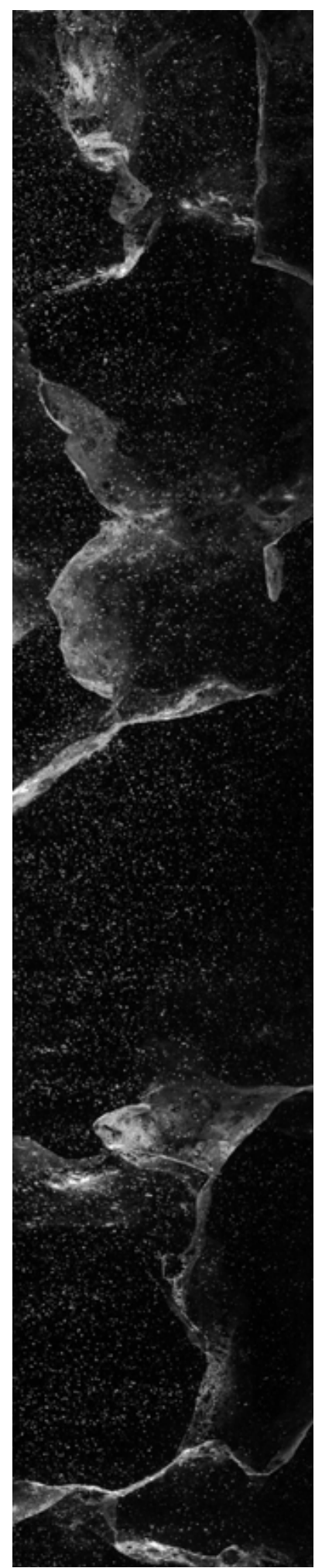

Fig. 2. Image of a section of sample "A" from 3070.10-3070.40 m depth (bag 5583). The slab is $3.4 \mathrm{~cm}$ thick and $6 \mathrm{~cm}$ wide. Ice crystals are rather large for Greenland: up to $10 \mathrm{~cm}$ across and grain boundaries are visible. This is due to the high temperature and very active crystal dynamics in the deepest part of the ice that is almost at the pressure melting point. 
Table 1. List of samples. The sample length is after removal of breaks and end pieces.

\begin{tabular}{lrccccc}
\hline Sample & \multicolumn{1}{c}{ Period } & $\begin{array}{c}\text { NGRIP Bag } \\
\text { numbers }\end{array}$ & $\begin{array}{c}\text { Depth } \\
\text { interval (m) }\end{array}$ & $\begin{array}{c}\text { Sample } \\
\text { length (m) }\end{array}$ & $\begin{array}{c}\text { Age } \\
\text { ss09sea (kyr) }\end{array}$ & $\begin{array}{c}\delta^{18} \mathrm{O} \\
(\%)\end{array}$ \\
\hline $\mathrm{A}$ & MIS5e/Eem & $5581-5584$ & $3069.00-3071.20$ & 1.98 & 122.0 & -32.4 \\
$\mathrm{~B}$ & MIS5e/GS-26 & $5528-5531$ & $3039.85-3042.05$ & 2.08 & 119.8 & -36.2 \\
$\mathrm{C}$ & GI-25 & $5447-5450$ & $2995.30-2997.50$ & 1.95 & 115.4 & -37.0 \\
\hline
\end{tabular}

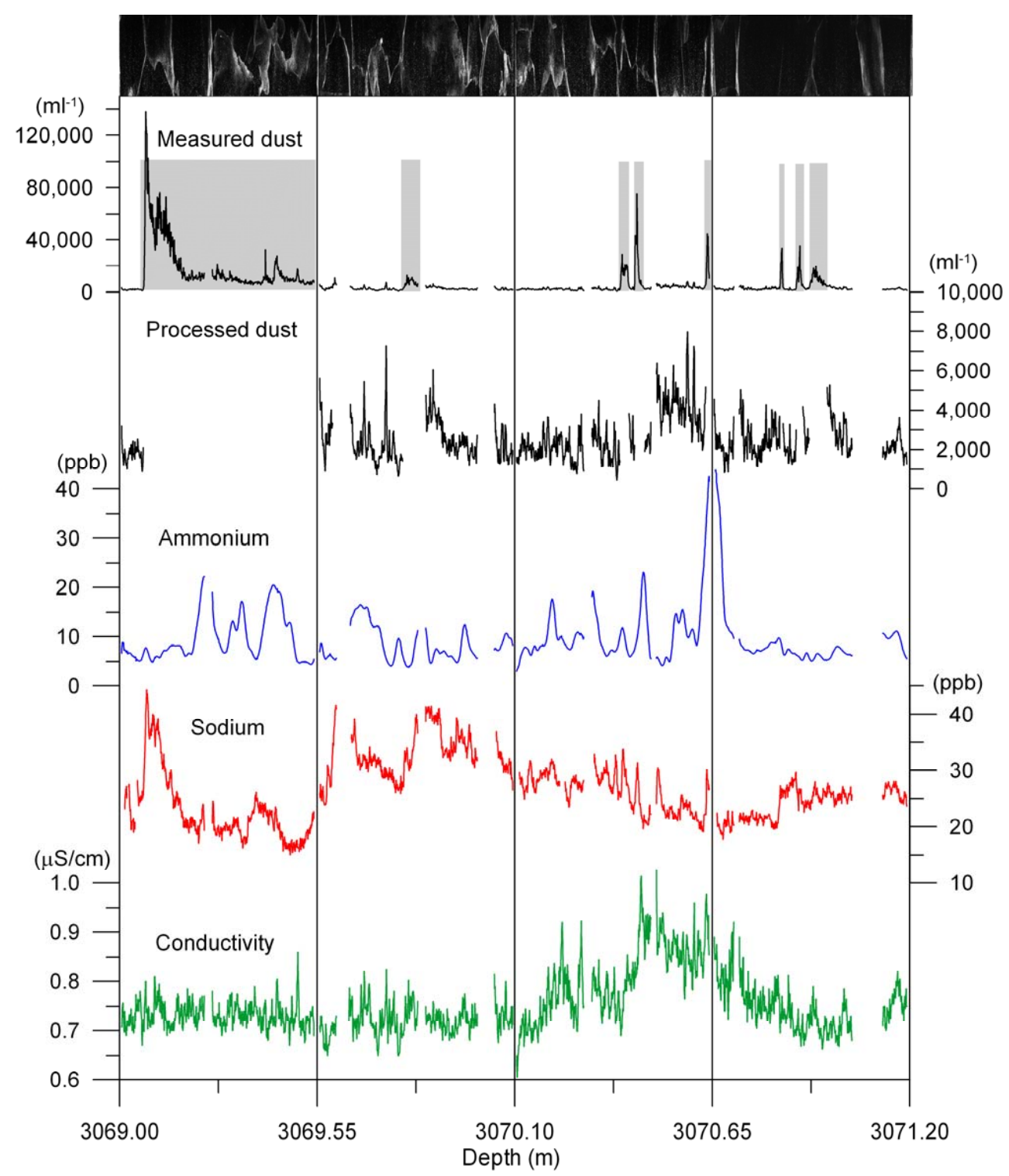

Fig. 3. Measured records of dust, ammonium, sodium, and conductivity from sample "A" shown together with the visual stratigraphy (top). The uppermost curve shows the measured dust profile including the contaminated sections that are indicated with gray bars. For the second dust curve, the contaminated sections are removed. Data gaps are caused by breaks in the core (that were removed), contamination issues (dust only), or analytical issues. Vertical lines indicate the $55 \mathrm{~cm}$ sections of the analyzed cores. 

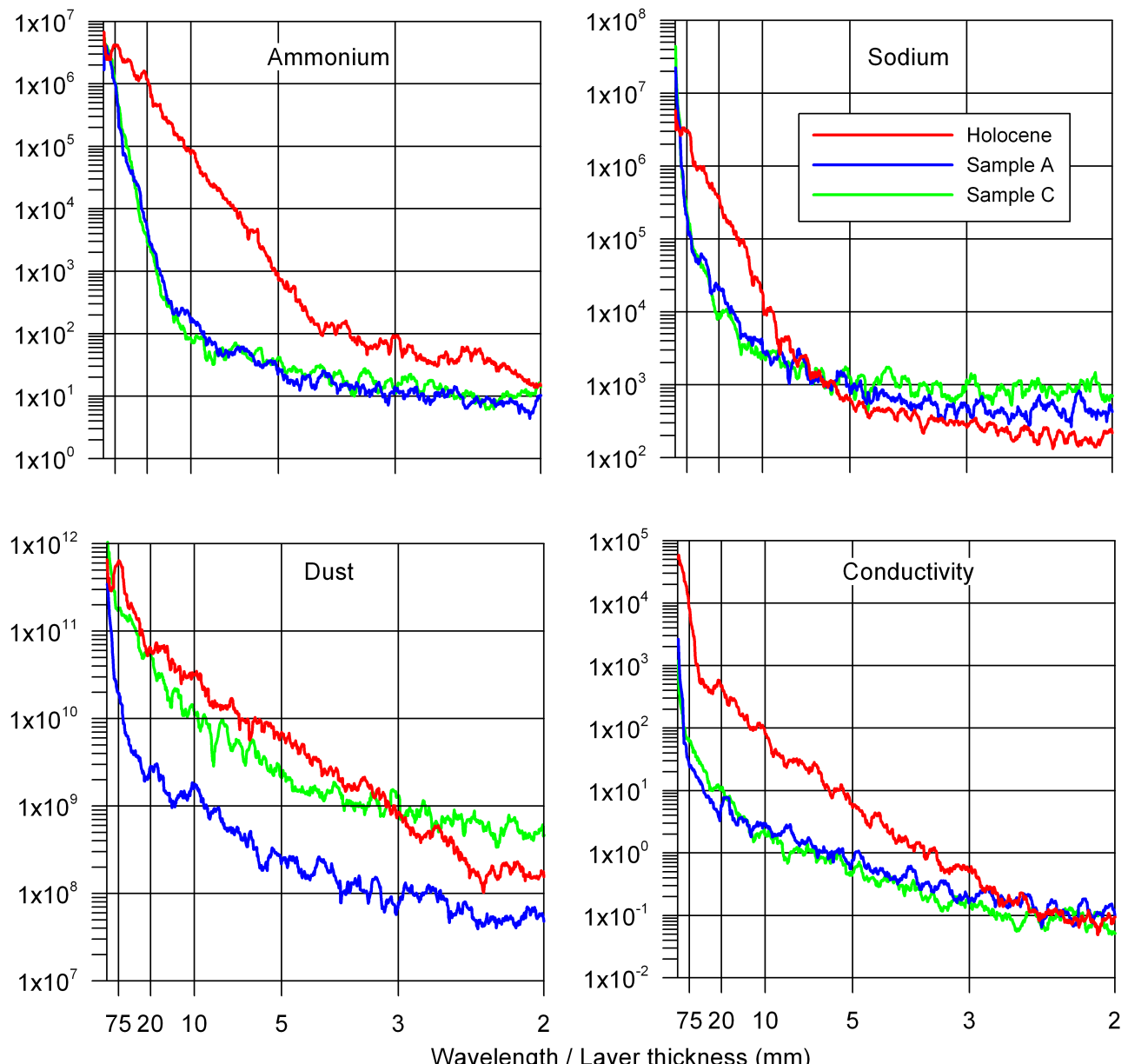

Fig. 4. Depth domain power density spectra comparing early Holocene, Eemian (sample "A"), and early glacial (sample "C") NGRIP records. The spectra are obtained by FFT of $2.0 \mathrm{~m}$ records in $1 \mathrm{~mm}$ depth resolution. The "wavelength/layer thickness" is calculated as 2.0 (m) times frequency. Holocene data are from Bigler et al. (2011). In the Holocene spectra a clear annual layer peak is visible at around $75 \mathrm{~mm}$, whereas the Eemian and glacial spectra show no clear indication of an annual peak. Data gaps are linearly interpolated.

early glacial sample "C" of the present study. The spectra are composed of a "signal" at lower frequencies (left hand side of spectra) and a noise level where the spectra flatten out at higher frequencies (right hand side of spectra). The data sets are obtained by the same analytical technique and with the same depth resolution (sample melt speed), so from an analytical point of view the spectra are directly comparable. If we assume similar deposition patterns for impurities deposited during the Eemian and the early Holocene, the difference between the power spectra from the two periods reflects the effects of ice deformation and impurity diffusion over a 100 ka period. Obviously, all of the measured parameters are affected by both processes, but the parameters appear not to be influenced in the same way.

A pure vertical compression of the ice would result in a "stretching" of the power spectrum along the x-axis and thereby an amplification of the signal at all frequencies, whereas impurity diffusion in the ice will dampen higher frequencies of the signal over time. The general change from Holocene to Eemian ice appears to be a dampening of signal at most frequencies, meaning that diffusion is the dominating process of the two, although ice layer thinning (compression) must be very important as well.

For dust, the power spectra of the Eemian and the early glacial have very similar shape, but the glacial sample has higher power at all frequencies due to the much stronger variability in dust concentration during the glacial period. As the influence of dust diffusion in the ice is likely to be low even over long periods, we would not expect the Eemian spectrum to be strongly influenced by diffusion as compared to the Holocene spectrum. The Eemian spectrum is, however, clearly influenced by some process that dampens the signal as compared to the Holocene. One mechanism that could explain this observation without involving dust diffusion would be rotation and deformation of ice crystals, which, to first order, would have an effect on the dust spectrum similar to that 
of diffusion. Based on our data alone, we can, however, not distinguish between those different mechanisms.

As the conductivity signal is a composite signal that involves all of the ions in the ice, the interpretation of its development over time is likely to be complex. We do note, however, that the Eemain and the early glacial spectra are very similar, suggesting that time rather than climate is the important factor for the shape of the conductivity power spectrum.

Ammonium is the most affected parameter that has clearly undergone a significant diffusion over the $100 \mathrm{kyr}$ period with a strong dampening of the signal. The effect is also evident from the record in depth space (Fig. 3), where the ammonium profile has been significantly smoothed as compared to a Holocene ammonium profile, which exhibits a prominent annual signal (Bigler et al., 2011). A similar effect has been observed for ammonium in old GRIP ice (Steffensen et al., 1997).

The Eemian sodium profile is also somewhat dampened as compared to its Holocene counterpart although apparently less than is the case for ammonium. A relatively low diffusivity of sodium and a strong binding of sodium in the ice lattice have also been observed for the Holocene section of the Antarctic Dome C ice core (Barnes et al., 2003).

\section{Absolute concentration levels}

The average concentration levels of the measured parameters are compared to early Holocene values from NGRIP obtained by the same analytical setup as applied in this study (Bigler et al., 2011) (Table 2).

Over the last glacial cycle, ammonium concentrations generally vary with climate, showing the highest concentrations during the MIS1 and MIS4 (Fuhrer et al., 1996; Mayewski et al., 1997). In this study, ammonium concentrations appear to be correlated with $\delta^{18} \mathrm{O}$, but the level is consistently lower than the early Holocene value. For dust, the Eemian concentration level of this study (sample "A") is only slightly lower than that of the early Holocene, and the samples consistently show the well-known Greenland pattern of higher concentrations for colder climate (Ruth et al., 2003). The conductivity values of the present study are consistently lower than that of the early Holocene by about a factor of two. The Eemian and early glacial values vary consistently with climate $\left(\delta^{18} \mathrm{O}\right)$, showing the lower the values, the warmer the climate.

There is a whole range of possible reasons for the observed differences in the impurity concentration levels of the early Holocene, the Eemian, and the early glacial. Obviously, changes in source areas, transport routes, and deposition patterns are major players (Fischer et al., 2007). Another reason for differences may be related to elevation changes of the Greenland ice sheet from period to period, which may have been important (Vinther et al., 2009). Furthermore, slow chemical reactions in the ice over the $110 \mathrm{ka}$ period or faster reactions in the deep warm ice may cause changes in the absolute levels. At this stage, however, we just note that, to first order, the Eemian levels are very comparable to those of the Early Holocene and that dust and ammonium appear to express a climatic dependence in concentrations.

\section{Annual layering}

In all of the analyzed ice, a clear stratigraphic signal is evident in both conductivity and dust records whenever they are available (Fig. 5 and Figs. S1-S3 in the Supplement). We associate the observed stratigraphy with annual layering.

The annual layers are counted following the scheme applied for the construction of the Greenland Ice Core Chronology 2005 (GICC05) (Rasmussen et al., 2006; Andersen et al., 2006): "certain" and "uncertain" annual layers are assigned along the profiles based on subjective evaluation for the likelihood of an annual layer. This quantitative error estimate has been applied systematically and successfully for the period 0-60 ka. In the present study, uncertain annual layers are counted as $0.5 \pm 1.0 \mathrm{yr}$ and introduce an uncertainty of about $14 \%$ for the counting, which is somewhat higher than the $5 \%$ generally found in the glacial NGRIP ice (Andersen et al., 2006). Note that because the layer counting is based on just one or two data series, the error estimate applied here is twice that of Andersen et al. (2006) where uncertain annual layers are counted as $0.5 \pm 0.5 \mathrm{yr}$. The full data set and layer counting are shown in Fig. S1-S3 and the results are summarized in Table 3.

We determine annual layer thicknesses clustering around $11 \mathrm{~mm}$, which is within the depth resolution of the analytical method for dust and conductivity (Bigler et al., 2011). Even for sodium, which is at the limit of its resolution to resolve those layers, the annual layering is occasionally observable. Unfortunately at this depth, the ammonium profile is too smoothed to reveal the seasonal pattern that is very pronounced in Holocene ice. Note that the low resolution of the ammonium profile is not due to limited resolution of the analytical technique.

Figure 6 shows power spectra of the impurity records in the time domain after applying the time scale resulting from the layer counting. In this domain, spectral peaks corresponding to the annual cycle are quite significant for all samples. In the Holocene, the annual spike is present for all four impurity records, whereas for the older samples there are no spikes for ammonium and sodium due to diffusion. In the Holocene, overtone peaks (at integer multiple frequencies) are seen for all components except sodium. Those are probably caused by (1) multiple annual peaks occurring for several components in high resolution in the Holocene and (2) the non-sinusoidal shape of the Holocene records in high depth resolution. 
Table 2. Absolute concentration levels of the measured parameters compared to early Holocene values.

\begin{tabular}{lccccccr}
\hline Sample & $\begin{array}{c}\text { Age } \\
(\mathrm{kyr})\end{array}$ & $\begin{array}{c}\delta^{18} \mathrm{O} \\
(\% o)\end{array}$ & $\begin{array}{c}\mathrm{NH}_{4} \\
(\mathrm{ppb})\end{array}$ & $\begin{array}{c}\mathrm{Na} \\
(\mathrm{ppb})\end{array}$ & $\begin{array}{c}\text { Dust } \\
\left(\mathrm{ml}^{-1}\right)\end{array}$ & $\begin{array}{c}\text { Cond } \\
\left(\mu \mathrm{S} \mathrm{cm}^{-1}\right)\end{array}$ & $\begin{array}{r}\text { Source } \\
\text { reference }\end{array}$ \\
\hline Holocene & 10.0 & -35.1 & 10.7 & 18.6 & 2716 & 1.19 & Bigler et al. (2011) \\
A & 122 & -32.4 & 9.5 & 26.3 & 2516 & 0.75 & This study \\
B & 120 & -36.2 & 6.3 & 34.9 & 5586 & 0.60 & This study \\
C & 116 & -37.0 & 5.4 & 31.6 & 6015 & 0.51 & This study \\
\hline
\end{tabular}

Table 3. Annual layer thicknesses (lambda) derived from the measured sections based on annual layer counting. The number of "certain" and "uncertain" annual layers results in total annual layers and error estimate. Lambdas of the modeled time scale ss09sea are shown for comparison.

\begin{tabular}{lcccccccc}
\hline Sample & $\begin{array}{c}\text { Sample } \\
\text { length }(\mathrm{m})\end{array}$ & $\begin{array}{c}\text { Certain } \\
(\mathrm{yr})\end{array}$ & $\begin{array}{c}\text { Uncertain } \\
(\mathrm{yr})\end{array}$ & $\begin{array}{c}\text { Total } \\
(\mathrm{yr})\end{array}$ & mean & max & min & ss09sea \\
\hline A & 1.98 & 161 & 29 & $175.5 \pm 29.0$ & 11.3 & 13.5 & 9.7 & 14.7 \\
B & 2.08 & 183 & 20 & $193.0 \pm 20.0$ & 10.8 & 12.0 & 9.8 & 11.7 \\
C & 1.95 & 162 & 26 & $175.0 \pm 26.0$ & 11.1 & 13.1 & 9.7 & 11.1 \\
\hline
\end{tabular}

In sections where annual layers are resolved in sodium, it is interesting to note the relative phasing among the measured parameters (Fig. 5): sodium spikes generally (but not consistently) fall between dust spikes, suggesting a seasonal pattern similar to that of the Holocene with sodium being a winter signal and dust arriving in spring (Rasmussen et al., 2006). Obviously, this conclusion is based on the assumption that the depth alignment of the different parameters is precise to the millimeter scale, which is probably pushing the precision a bit.

\section{Implications for NGRIP time scale}

The published time scale for the deepest part of the NGRIP ice core is the modeled ss09sea time scale that is based on the use of a fixed point at $110 \mathrm{ka}$ and that takes into account the basal melt at NGRIP (Johnsen et al., 2001; Andersen et al., 2006). An alternative time scale for the early glacial period is based on comparison of Greenland and Antarctic gas records (Capron et al., 2010). Generally, the ss09sea chronology of the early glacial is confirmed by several independent records, such as U/Th dated stalagmite records from the alps (Drysdale et al., 2007; Boch et al., 2011) and China (Wang et al., 2008; Xia et al., 2007), but time scale uncertainties do allow for some flexibility in the exact timing of abrupt climate transitions.

Based on our data alone, we cannot evaluate the accuracy of the various time scales, but we can constrain the NGRIP annual layer thicknesses within the investigated period. Our derived annual layer thicknesses basically confirm the modeled NGRIP time scale (ss09sea) for the deepest part of the ice core, although it suggests that the duration of the MIS5e/Eemian section of the ice core may be somewhat longer than estimated by the model (Fig. 7 and Table 3). Assuming a rather constant annual layer thickness of the Eemian NGRIP ice as suggested by samples " $A$ " and "B" implies a duration of the Eemian NGRIP section of $4 \mathrm{ka}$ or up to $1 \mathrm{ka}$ longer than according to the model.

A likely reason for a slightly biased annual layer thickness estimation in the ss09sea model during the Eemian would be an inaccurate estimate of basal melt rates at NGRIP that are quite poorly constrained. Another explanation for the discrepancy between our Eemian annual layer estimate and that of the model would be a partial breakdown of the $\delta^{18} \mathrm{O}$ accumulation relation in the Eemian period caused, for example, by significant elevation changes of the ice cap or by changes in the position of the ice divide over time. Such a breakdown is known to have occurred in MIS2 where ss09sea overestimates the annual layer thickness by some $20 \%$ for a period of several thousands of years (Svensson et al., 2006).

\section{Crystal boundaries and impurities}

It has been suggested that very significant diffusion of soluble ice core impurities may appear under warm conditions similar to those found in the NGRIP Eemian ice (Rempel et al., 2001; Dash et al., 2006). The so-called anomalous diffusion appears in a water-vein system of the ice crystal grain boundaries. The possible existence of liquid veins in the ice sheets has important implications for microbiological and molecular analyses of ice cores (Miteva et al., 2009; Price, 2000). Recently, the occurrence of 

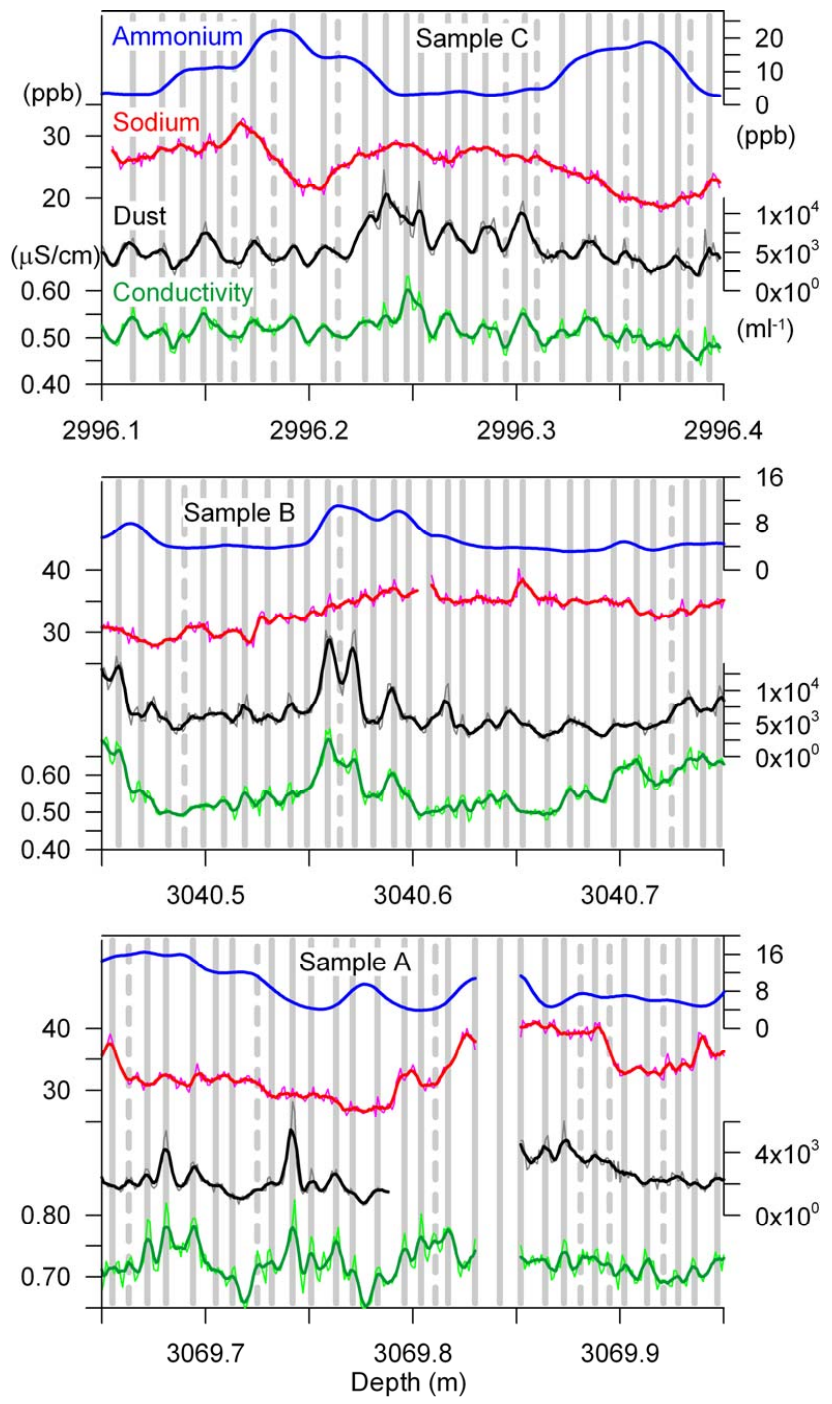

Fig. 5. Examples of annual layer counting in samples "A", "B", and "C", respectively. Annual layers are resolved in dust (black) and conductivity (green) and occasionally in sodium (red), whereas the ammonium signal (blue) is affected by post-depositional processes. "Certain" and "uncertain" annual layers are indicated with solid and dashed grey vertical lines, respectively. The measurements are shown in $1 \mathrm{~mm}$ resolution (thin light curves) as well as in $5 \mathrm{~mm}$ smoothed resolution (thick dark curves).

long-term post-depositional processes involving a rearrangement of impurities via migration in the vein network has been observed in the deepest part of the Antarctic Dome C record (Traversi et al., 2009).

Our results demonstrate that whereas there has been a significant displacement of ammonium ions in the deepest NGRIP ice, dust particles are not significantly affected by such processes. Indeed, the annual layering is preserved in dust across ice crystals that are tens of centimeters across (Fig. 2), and there are no elevated impurity concentrations within the ice crystal boundaries (except for dust contamination presumably caused by drilling fluid). Not even the strongly diffused ammonium appears to have concentrated in grain boundaries, which challenges the ideas of an active liquid vein system in the deep central Greenland ice. As the power signal of the Eemian dust has a somewhat different shape as compared to Holocene (Fig. 4), it is likely that large impurities such as dust are displaced during deformation and rotation of ice crystals. The ice crystal boundaries migration that is active within the entire ice sheet and that the Eemian ice has experienced for $120 \mathrm{ka}$, has, however, not resulted in any significant displacement of the solid impurities in the Greenland ice.

Whereas the preservation of annual layers could be anticipated for the large and non-diffusive dust particles, it is not so obvious why a seasonal cycle is also observed in the conductivity record and even occasionally in the sodium record. One can speculate whether this signal in the Eemian records is derived from the original annual signal that was deposited with the snow or if diffusion and rearrangement of impurities over long time scales may have favored soluble impurities to cluster around solid particles in the ice. Indeed, the lack of a strong annual peak in the early Holocene conductivity power spectra (Figs. 4 and 6) suggests that the annual signal observed for the Eemian conductivity record may be a result of long-term post-depositional processes. On the other hand, if sodium shows a seasonal winter peak between the dust peaks, this suggests that we still see the original sodium signal in the Eemian ice. This finding is consistent with that of Ohno et al. (2005), who observed in ice from the Antarctic Dome F core that certain soluble impurities can form salts that stay fixed in the ice lattice.

\section{Conclusions}

Three sections of ice from the Eemian and the glacial interception in the deepest part of the NGRIP ice core have been analyzed by a new high-resolution CFA system for concentrations of sodium, ammonium, dust, and melt water conductivity. The absolute levels of all measured components are very comparable to those of early Holocene NGRIP ice.

Surprisingly, it is possible to identify annual layers in the records of dust and conductivity in all of the analyzed ice except for sections where dust is contaminated by drill liquid. It is the first time annual layers have been identified in ice from the last interglacial period in Greenland, and our results suggest that annual layering is likely to be preserved throughout the NGRIP ice core despite very active crystal dynamics and temperatures close to the melting point near bedrock. Continuous analysis and stratigraphic dating of the very deepest NGRIP ice may, however, not be feasible due to a rather poor ice core quality and a pronounced dust contamination. The samples selected for this study were high-quality ice core pieces but still the contamination issue is significant. 

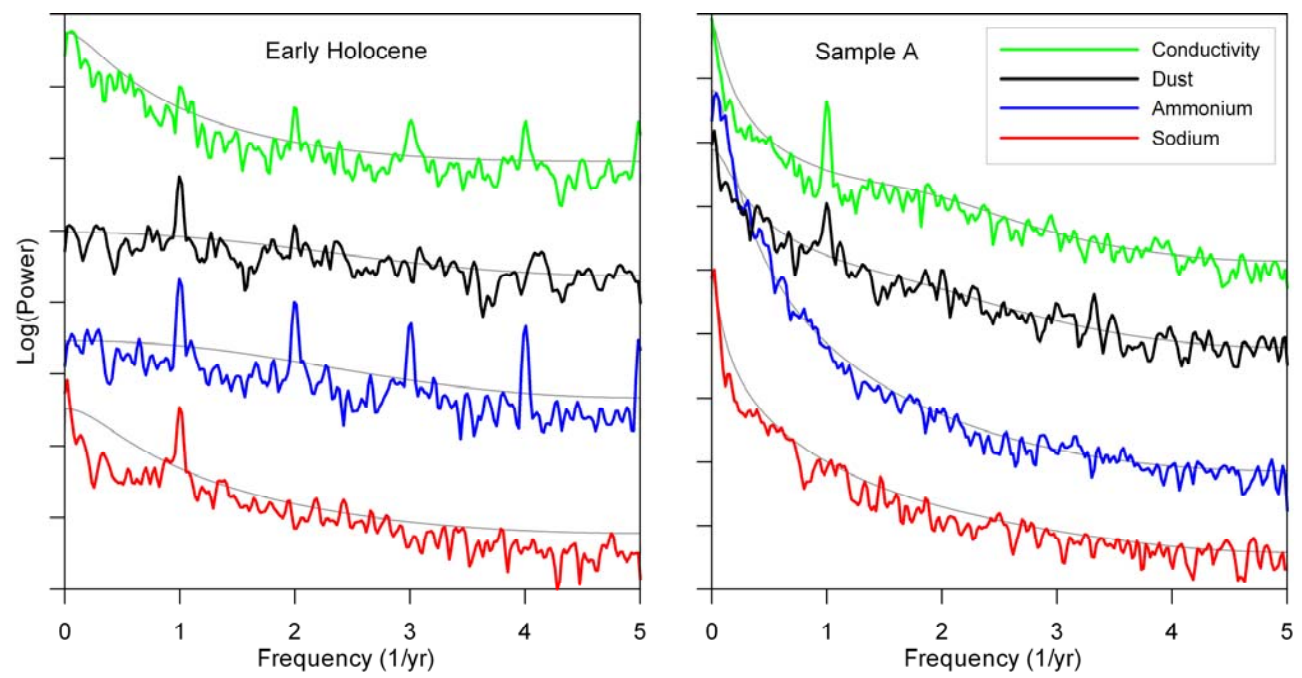

Fig. 6. Time domain power density spectra comparing early Holocene and Eemain (sample "A") NGRIP impurity records. The records were placed on a floating time scale based on annual layer counting. The early Holocene sample covers a $11.0 \mathrm{~m}$ ice core section (1378.30$1389.30 \mathrm{~m}$ depth about $10 \mathrm{~b} 2 \mathrm{k}$ ) in which 148 certain annual layers were identified (from Bigler et al., 2011). Sample "A" covers a $2.2 \mathrm{~m}$ core section in which 190 annual layers have been identified (Table 3). Both 'certain' and 'uncertain' annual layers are included. Grey lines indicate $95 \%$ confidence limits from simulation of noise spectra. The spectra have been shifted vertically for clarity, but all spectra have comparable units. Larger missing sample sections were skipped, whereas shorter data gaps have been linearly interpolated.

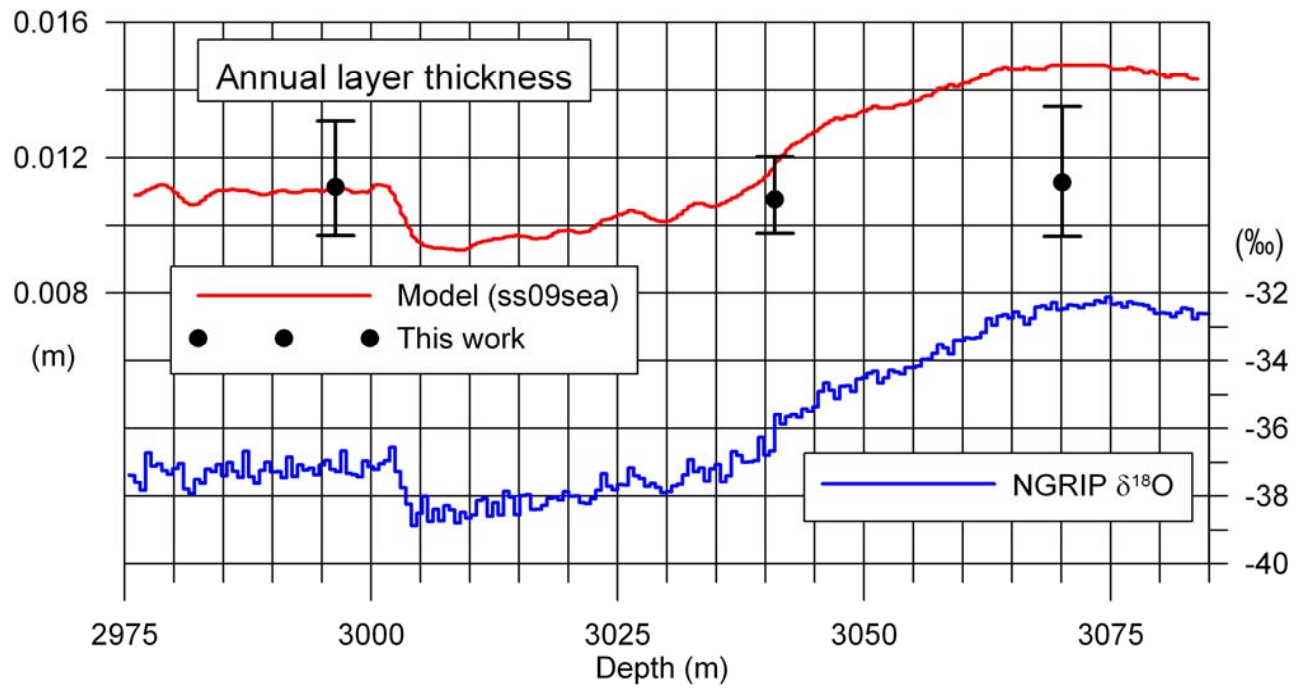

Fig. 7. NGRIP $\delta^{18} \mathrm{O}$ and annual layer thicknesses of ss0sea compared to those of the present study.

To first order, our analyses confirm the modeled NGRIP time scale (ss09sea) in the deepest part of the NGRIP ice core. The determination of mean annual layer thicknesses around $11 \mathrm{~mm}$ in all three samples does, however, suggest that the MIS5e section of the core may be longer than predicted by the model by up to $1 \mathrm{ka}$.

The preservation of annual layers in the deep and warm NGRIP ice somehow challenges the ideas of an active liquid vein system in warm glacier ice that is put forward in several mainly theoretical papers. In our data, we see no sign of elevated impurity concentrations in the grain boundaries, not even for ammonium that has clearly undergone a very significant diffusion over the glacial period.

The determination of annual layers of down to $1 \mathrm{~cm}$ thickness in deep Greenland ice opens the possibility for stratigraphic dating of a wide range of ice cores from both Greenland and Antarctica. In Greenland, annual layer thicknesses in most of the early glacial section of the NGRIP ice core exceed $1 \mathrm{~cm}$. In Antarctica, the EDML ice core has centimeter thick annual layers throughout most of the glacial period, 
whereas both Dome F and Dome $\mathrm{C}$ are believed to have annual layers exceeding $1 \mathrm{~cm}$ during MIS 5e. Potentially, stratigraphic ice core dating of the entire last glacial cycle should be possible in both Hemispheres.

\section{Supplementary material related to this article is available online at: http://www.clim-past.net/7/1427/2011/ cp-7-1427-2011-supplement.pdf.}

Acknowledgements. This work is a contribution to the NGRIP ice core project, which is directed and organized by the Ice and Climate Research Group at the Niels Bohr Institute, University of Copenhagen. It is being supported by funding agencies in Denmark (SNF), Belgium (FNRS-CFB), France (IFRTP and INSU/CNRS), Germany (AWI), Iceland (RannIs), Japan (MEXT), Sweden (SPRS), Switzerland (SNF) and the United States of America (NSF). This work is also a contribution to the Copenhagen Ice Core Dating Initiative, which was supported by a grant from the Carlsberg Foundation. Acknowledge CIC and KUP.

Edited by: L. Skinner

\section{References}

Andersen, K. K., Svensson, A., Rasmussen, S. O., Steffensen, J. P., Johnsen, S. J., Bigler, M., Röthlisberger, R., Ruth, U., SiggaardAndersen, M.-L., Dahl-Jensen, D., Vinther, B. M., and Clausen, H. B.: The Greenland Ice Core Chronology 2005, 15-42 ka. Part 1: constructing the time scale, Quaternary Sci. Rev., 25, 32463257, 2006.

Barnes, P. R. F., Wolff, E. W., Mader, H. M., Udisti, R., Castellano, E., and Röthlisberger, R.: Evolution of chemical peak shapes in the Dome C, Antarctica, ice core, J. Geophys. Res., 108, 4126, doi:4110.1029/2002JD002538, 2003.

Bigler, M., Svensson, A., Kettner, E., Vallelonga, P., Nielsen, M. E., and Steffensen, J. P.: Optimization of High-Resolution Continuous Flow Analysis for Transient Climate Signals in Ice Cores, Environ. Sci. Technol., 45, 4483-4489, doi:10.1021/es200118j, 2011.

Boch, R., Cheng, H., Spötl, C., Edwards, R. L., Wang, X., and Häuselmann, Ph.: NALPS: a precisely dated European climate record 120-60 ka, Clim. Past Discuss., 7, 1049-1072, doi:10.5194/cpd-7-1049-2011, 2011.

Brauer, A., Allen, J. R. M., Mingram, J., Dulski, P., Wulf, S., and Huntley, B.: Evidence for last interglacial chronology and environmental change from Southern Europe, Proc. Natl. Acad. Sci., 104, 450-455, 2007.

Capron, E., Landais, A., Lemieux-Dudon, B., Schilt, A., MassonDelmotte, V., Buiron, D., Chappellaz, J., Dahl-Jensen, D., Johnsen, S., Leuenberger, M., Loulergue, L., and Oerter, H.: Synchronising EDML and NorthGRIP ice cores using delta O18 of atmospheric oxygen (delta O-18(atm)) and $\mathrm{CH} 4$ measurements over MIS5 (80-123 kyr), Quaternary Sci. Rev., 29, 222234, doi:10.1016/j.quascirev.2009.07.014, 2010.

Cheng, H., Edwards, R. L., Broecker, W. S., Denton, G. H., Kong, X. G., Wang, Y. J., Zhang, R., and Wang, X. F.: Ice Age Termi- nations, Science, 326, 248-252, doi:10.1126/science.1177840, 2009.

Couchoud, I., Genty, D., Hoffmann, D., Drysdale, R., and Blamart, D.: Millennial-scale climate variability during the Last Interglacial recorded in a speleothem from south-western France, Quaternary Sci. Rev., 28, 3263-3274, 2009.

Dahl-Jensen, D., Gundestrup, N., Miller, H., Watanabe, O., Johnsen, S. J., Steffensen, J. P., Clausen, H. B., Svensson, A., and Larsen, L. B.: The NorthGRIP deep drilling program, Ann. Glaciol., 35, 1-4, 2002.

Dahl-Jensen, D., Gundestrup, N., Gorgineni, S. P., and Miller, H.: Basal melt at NorthGRIP modeled from borehole, ice-core and radio-echo sounder observations, Ann. Glaciol., 37, 207-212, 2003.

Dash, J. G., Rempel, A. W., and Wettlaufer, J. S.: The physics of premelted ice and its geophysical consequences, Rev. Mod. Phys., 78, 695-741, doi:10.1103/RevModPhys.78.695, 2006.

Drysdale, R. N., Zanchetta, G., Hellstrom, J. C., Fallick, A. E., McDonald, J., and Cartwright, I.: Stalagmite evidence for the precise timing of North Atlantic cold events during the early last glacial, Geology, 35, 77-80, 2007.

Drysdale, R. N., Hellstrom, J. C., Zanchetta, G., Fallick, A. E., Goni, M. F. S., Couchoud, I., McDonald, J., Maas, R., Lohmann, G., and Isola, I.: Evidence for Obliquity Forcing of Glacial Termination II, Science, 325, 1527-1531, doi:10.1126/science.1170371, 2009.

Faria, S. H., Freitag, J., and Kipfstuhl, S.: Polar ice structure and the integrity of ice-core paleoclimate records, Quaternary Sci. Rev., 29, 338-351, doi:10.1016/j.quascirev.2009.10.016, 2010.

Fischer, H., Siggaard-Andersen, M.-L., Ruth, U., Röthlisberger, R., and Wolff, E.: Glacial/interglacial changes in mineral dust and sea-salt records in polar ice cores: Sources, transport, and deposition, Rev. Geophys., 45, RG1002, doi:1010.1029/2005RG000192, 2007.

Fuhrer, K., Neftel, A., Anklin, M., Staffelbach, T., and Legrand, M.: High-resolution ammonium ice core record covering a complete glacial-interglacial cycle, J. Geophys. Res.-Atmos., 101, 41474164, 1996.

Johnsen, S. J., Dahl-Jensen, D., Gundestrup, N., Steffensen, J. P., Clausen, H. B., Miller, H., Masson-Delmotte, V., Sveinbjörnsdottir, A. E., and White, J.: Oxygen isotope and palaeotemperature records from six Greenland ice-core stations: Camp Century, Dye-3, GRIP, GISP2, Renland and NorthGRIP, J. Quaternary Sci., 16, 299-307, 2001.

Kopp, R. E., Simons, F. J., Mitrovica, J. X., Maloof, A. C., and Oppenheimer, M.: Probabilistic assessment of sea level during the last interglacial stage, Nature, 462, 863-U851, doi:10.1038/nature08686, 2009.

Landais, A., Masson-Delmotte, V., Jouzel, J., Raynaud, D., Johnsen, S., Huber, C., Leuenberger, M., Schwander, J., and Minster, B.: The glacial inception as recorded in the NorthGRIP Greenland ice core: Timing, structure and associated abrupt temperature changes, Clim. Dynam., 26, 273-284, 2006.

Mayewski, P. A., Meeker, L. D., Twickler, M. S., Whitlow, S., Yang, Q., Lyons, W. B., and Prentice, M.: Major features and forcing of high-latitude Northern Hemisphere atmospheric circulation using a 110,000-year-long glaciochemical series, J. Geophys. Res., 102, 26345-26366, 1997.

Miteva, V., Teacher, C., Sowers, T., and Brenchley, J.: Comparison 
of the microbial diversity at different depths of the GISP2 Greenland ice core in relationship to deposition climates, Environ. Microbiol., 11, 640-656, doi:10.1111/j.1462-2920.2008.01835.x, 2009.

North Greenland Ice Core Project members: High-resolution record of Northern Hemisphere climate extending into the last interglacial period, Nature, 431, 147-151, 2004.

Ohno, H., Igarashi, M., and Hondoh, T.: Salt inclusions in polar ice core: Location and chemical form of water-soluble impurities, Earth Planet. Sci. Lett., 232, 171-178, 2005.

Price, P. B.: A habitat for psychrophiles in deep Antarctic ice, Proc. Natl. Acad. Sci. USA, 97, 1247-1251, 2000.

Rasmussen, S. O., Andersen, K. K., Svensson, A. M., Steffensen, J. P., Vinther, B. M., Clausen, H. B., Siggaard-Andersen, M.L., Johnsen, S. J., Larsen, L. B., Dahl-Jensen, D., Bigler, M., Röthlisberger, R., Fischer, H., Goto-Azuma, K., Hansson, M. E., and Ruth, U.: A new Greenland ice core chronology for the last glacial termination, J. Geophys. Res., 111, D06102, doi:06110.01029/02005JD006079, 2006.

Rempel, A. W., Waddington, E. D., Wettlaufer, J. S., and Worster, M. G.: Possible displacement of the climate signal in ancient ice by premelting and anomalous diffusion, Nature, 411, 568-571, 2001.

Ruth, U., Wagenbach, D., Steffensen, J. P., and Bigler, M.: Continuous record of microparticle concentration and size distribution in the central Greenland NGRIP ice core during the last glacial period, J. Geophys. Res., 108, 4098, doi:4010.1029/2002JD002376, 2003.

Shackleton, N. J., Sánchez-Goñi, M. F., Pailler, D., and Lancelot, Y.: Marine Isotope Substage 5e and the Eemian Interglacial, Global Planet. Change, 36, 151-155, 2003.

Steffensen, J. P., Clausen, H. B., Hammer, C. U., Legrand, M., and De Angelis, M.: The chemical composition of cold events within the Eemian section of the Greenland Ice Core Project ice core from Summit, Greenland., J. Geophys. Res., 102, 26747-26754, 1997.

Suwa, M., von Fischer, J. C., Bender, M. L., Landais, A., and Brook, E. J.: Chronology reconstruction for the disturbed bottom section of the GISP2 and the GRIP ice cores: Implications for Termination II in Greenland, J. Geophys. Res., 111, D02101, doi:02110.01029/02005JD006032, 2006.
Svensson, A., Nielsen, S. W., Kipfstuhl, S., Johnsen, S. J., Steffensen, J. P., Bigler, M., Ruth, U., and Röthlisberger, R.: Visual stratigraphy of the North Greenland Ice Core Project (NorthGRIP) ice core during the last glacial period, J. Geophys. Res., 110, D02108, doi:02110.01029/02004JD005134, 2005.

Svensson, A., Andersen, K. K., Bigler, M., Clausen, H. B., DahlJensen, D., Davies, S. M., Johnsen, S. J., Muscheler, R., Rasmussen, S. O., Röthlisberger, R., Steffensen, J. P., and Vinther, B. M.: The Greenland Ice Core Chronology 2005, 15-42 ka. Part 2: comparison to other records, Quaternary Sci. Rev., 25, 32583267, 2006.

Svensson, A., Andersen, K. K., Bigler, M., Clausen, H. B., DahlJensen, D., Davies, S. M., Johnsen, S. J., Muscheler, R., Parrenin, F., Rasmussen, S. O., Röthlisberger, R., Seierstad, I., Steffensen, J. P., and Vinther, B. M.: A 60000 year Greenland stratigraphic ice core chronology, Clim. Past, 4, 47-57, doi:10.5194/cp-4-472008, 2008.

Traversi, R., Becagli, S., Castellano, E., Marino, F., Rugi, F., Severi, M., de Angelis, M., Fischer, H., Hansson, M., Stauffer, B., Steffensen, J. P., Bigler, M., and Udisti, R.: Sulfate Spikes in the Deep Layers of EPICA-Dome C Ice Core: Evidence of Glaciological Artifacts, Environ. Sci. Technol., 43, 8737-8743, doi:10.1021/es901426y, 2009.

Turney, C. S. M. and Jones, R. T.: Does the Agulhas Current amplify global temperatures during super-interglacials?, J. Quaternary Sci., 25, 839-843, doi:10.1002/jqs.1423, 2010.

Vinther, B. M., Buchardt, S. L., Clausen, H. B., Dahl-Jensen, D., Johnsen, S. J., Fisher, D. A., Koerner, R. M., Raynaud, D., Lipenkov, V., Andersen, K. K., Blunier, T., Rasmussen, S. O., Steffensen, J. P., and Svensson, A. M.: Holocene thinning of the Greenland ice sheet, Nature, 461, 385-388, doi:10.1038/nature08355, 2009.

Wang, Y. J., Cheng, H., Edwards, R. L., Kong, X. G., Shao, X. H., Chen, S. T., Wu, J. Y., Jiang, X. Y., Wang, X. F., and An, Z. S.: Millennial- and orbital-scale changes in the East Asian monsoon over the past 224,000 years, Nature, 451, 1090-1093, doi:10.1038/nature06692, 2008.

Xia, Z., Kong, X., Jiang, X., and Cheng, H.: Precise dating of East-Asian-Monsoon D/O events during 95-56 ka BP: Based on stalagmite data from Shanbao Cave at Shennongjia, China, Sci. China Ser. D, 50, 228-235, 2007. 